\title{
Presence of anti-Toxoplasma gondii, -Neospora caninum, - Leishmania spp. and -Ehrlichia canis antibodies in free-ranging maned wolves (Chrysocyon brachyurus) in the northeastern region of the state of São Paulo, Brazil
}

\author{
Presença de anticorpos anti-Toxoplasma gondii, -Neospora caninum, -Leishmania spp.e - \\ Ehrlichia canis em lobos-guará (Chrysocyon brachyurus) de vida livre na Região Nordeste do \\ Estado de São Paulo, Brasil
}

\begin{abstract}
Solange de OLIVEIRA ${ }^{1}$; Paulo Sérgio Ribeiro MATTOS ${ }^{2}$; Keiko Kusamura MATTOS ${ }^{3}$; Rogério Hartung TOPPA ${ }^{4}$; Andréa Pereira COSTA ${ }^{1}$; Arlei MARCILI ${ }^{1}$; Juliana Isabel Giuli Silva FERREIRA ${ }^{1}$; Felipe da Silva KRAWCZAK ${ }^{1}$; Marcelo Bahia LABRUNA ${ }^{1}$; Solange Maria GENNARI ${ }^{1}$; Hilda Fátima de Jesus PENA ${ }^{1}$
\end{abstract}
${ }^{1}$ Universidade de São Paulo, Faculdade de Medicina Veterinária e Zootecnia, Departamento de Medicina Veterinária Preventiva e Saúde Animal, São Paulo - SP, Brazil
${ }^{2}$ Empresa Brasileira de Pesquisa Agropecuária, Embrapa Recursos Genéticos e Biotecnologia, Prédio de Conservação de Germoplasma, Brasília - DF, Brazil
${ }^{3}$ Médica Veterinária autônoma
${ }^{4}$ Universidade Federal de São Carlos, Núcleo de Estudos em Ecologia da Paisagem e Conservação, Departamento de Ciências Ambientais, Sorocaba - SP, Brazil

\begin{abstract}
The maned wolf (Chrysocyon brachyurus), an inhabitant of the Brazilian savanna, is considered the largest canid of South America and is classified as a near-threatened species by the International Union for Conservation of Nature (IUNC). The purpose of this study was to investigate the presence of antibodies against Toxoplasma gondii, -Neospora caninum, Leishmania spp., and -Ehrlichia canis in free-ranging maned wolves in the northeastern region of the state of São Paulo, Brazil. Of the 17 serum samples tested by the indirect fluorescent antibody test (IFAT), 88.2\% (15/17), 17.6\% (3/17) and 52.9\% (9/17) showed anti-T. gondii, -Leishmania spp., and -E. canis antibodies, respectively. None of the studied maned wolves tested positive for N. caninum antibodies. Our results indicated the exposure of free-ranging maned wolves to the agents in question. The presence of industrial complexes, extensive agriculture and habitat fragmentation in the northeastern region of the state of São Paulo puts these wild animals in proximity to urban areas, possibly contributing to the transmission of diseases between wild and domestic animals and human beings.
\end{abstract}

Keywords: Maned wolf. Toxoplasma gondii. Neospora caninum. Leishmania spp.. Ehrlichia canis.

\section{Resumo}

O lobo-guará (Chrysocyon brachyurus) habita o ecossistema de Cerrado e é considerado o maior canídeo da América do Sul e uma espécie ameaçada de extinção pela "International Union for Conservation of Nature" (IUNC). O objetivo desse estudo foi investigar a presença de anticorpos anti-Toxoplasma gondii, -Neospora caninum, -Leishmania spp. e-Ehrlichia canis em lobosguará da região nordeste do estado de São Paulo, Brasil. Das 17 amostras de soro testadas por meio da reação de imunofluorescência indireta (RIFI), 88,2\% (15/17), 17,6\% (3/17) e 52,9\% (9/17) apresentaram anticorpos anti-T. gondii, Leishmania spp. e -E. canis, respectivamente. Todos os animais testados foram soronegativos para N. caninum. Esses resultados indicam a exposição dos lobos-guará dessa região aos agentes pesquisados. A presença de um complexo industrial, agricultura extensiva e fragmentação de habitat na região nordeste do estado de São Paulo, favorece a proximidade desses animais silvestres a ambientes urbanos o que pode contribuir para a transmissão de doenças entre os animais silvestres, domésticos e o homem.

Palavras-chave: Lobo-guará. Toxoplasma gondii. Neospora caninum. Leishmania spp.. Ehrlichia canis. 
Correspondence to:

Hilda Fátima de Jesus Pena

Universidade de São Paulo, Faculdade de Medicina Veterinária e Zootecnia, Departamento de Medicina Veterinária Preventiva e Saúde Animal, VPS/FMVZ/USP Av. Prof. Dr. Orlando Marques de Paiva, 87 CEP 05508-270, São Paulo, SP, Brazil

e-mail:hfpena@usp.br

Received: 27/11/2015

Approved: 01/06/2016

\section{Introduction}

The maned wolf (Chrysocyon brachyurus) is considered the largest canid of South America and inhabits the Brazilian savanna. The species is classified as "near threatened" by the International Union for Conservation of Nature (IUCN) in the Red List of 2008 (RODDEN et al., 2008) and "vulnerable" by the Brazilian Institute of the Environment and Renewable Natural Resources [Instituto Brasileiro do Meio Ambiente e dos Recursos Naturais Renováveis, IBAMA] (CHIARELLO et al., 2008).

Toxoplasma gondii and Neospora caninum are intracellular protozoan parasites that can infect a large variety of hosts. Felids and some canids are the definitive hosts of $T$. gondii and $N$. caninum, respectively (DUBEY; BEATTIE, 1988; DUBEY, 2013). T. gondii has been isolated from many species of domestic and wild animals (DUBEY, 2010), unlike $N$. caninum, for which the isolation of viable parasites is rare (DUBEY; SCHARES, 2011).

Visceral leishmaniasis (VL) is a zoonotic disease caused by Leishmania (Leishmania) infantum chagasi and mainly transmitted by the phlebotomine Lutzomyia longipalpis (SANTOS et al., 1998). A large diversity of mammals can be infected by Leishmania spp., whereas domestic dogs are the main reservoir of L. infantum chagasi in the domestic environment. Wild canids such as the crab-eating fox (Cerdocyon thous), hoary zorro (Lycalopex vetulus), bush dog (Speothos venaticus) and maned wolf may play a role in VL epidemiology in the wild environment
(FIGUEIREDO et al., 2008; LUPPI et al., 2008; FERREIRA et al., 2013).

Ehrlichia canis is the primary etiological agent of canine monocytic ehrlichiosis (CME), a tick-borne disease transmitted by Rhipicephalus sanguineus. This multisystemic disease manifests itself in acute, subclinical and chronic forms (YU et al., 2007; STICH et al., 2008). E. canis may affect domestic dogs around the world (YU et al., 2007).

Anti-T. gondii, -N. caninum or -Leishmania sp. antibodies have been reported in wild and/or captive maned wolves in Brazil by few serological surveys (VITALIANO et al., 2004; CURI et al., 2006; CURI et al., 2010). To complement these results, the purpose of this study was to investigate the presence of antibodies against T. gondii, N. caninum, Leishmania spp. and $E$. canis in free-ranging maned wolves in the northeastern region of the state of São Paulo, Brazil.

\section{Material and Methods}

\section{Ethics committee}

All animals were handled in accordance with protocols approved by the Brazilian Institute of Natural Resources and Environment (IBAMA; Process n. 02027.005551/00-86).

\section{Study area and sample collection}

The study area was the northeastern region of the state of São Paulo, Brazil, including the Jataí Ecological Station in Luíz Antônio County. The maned wolves were trapped from 2000 to 2003.

An investigative survey conducted with residents around the study area was performed to identify the presence of the maned wolf and to determine the trails used by the animals. The locations where animals were trapped are shown in figure 1. Modified traps were placed along the trails (DIETZ, 1984). All 17 trapped animals (nine males and eight females) were anesthetized by intramuscular injection using a blowgun and homemade darts loaded with a combination of tiletamine hydrochloride and 
zolazepam hydrochloride $\left(\right.$ Zoletil $^{\circledR} 100$, Virbac ${ }^{\circledR}$ ), at 7.0 $\mathrm{mg} / \mathrm{Kg}$ as described by Novaes (1997).

Blood samples were collected from the cephalic vein, and serum samples were separated by centrifugation and kept frozen at $-20^{\circ} \mathrm{C}$ until the serological analyses. After sample collection, the animals were kept inside the traps until they had completely recovered from anesthesia, and then released to their habitat.

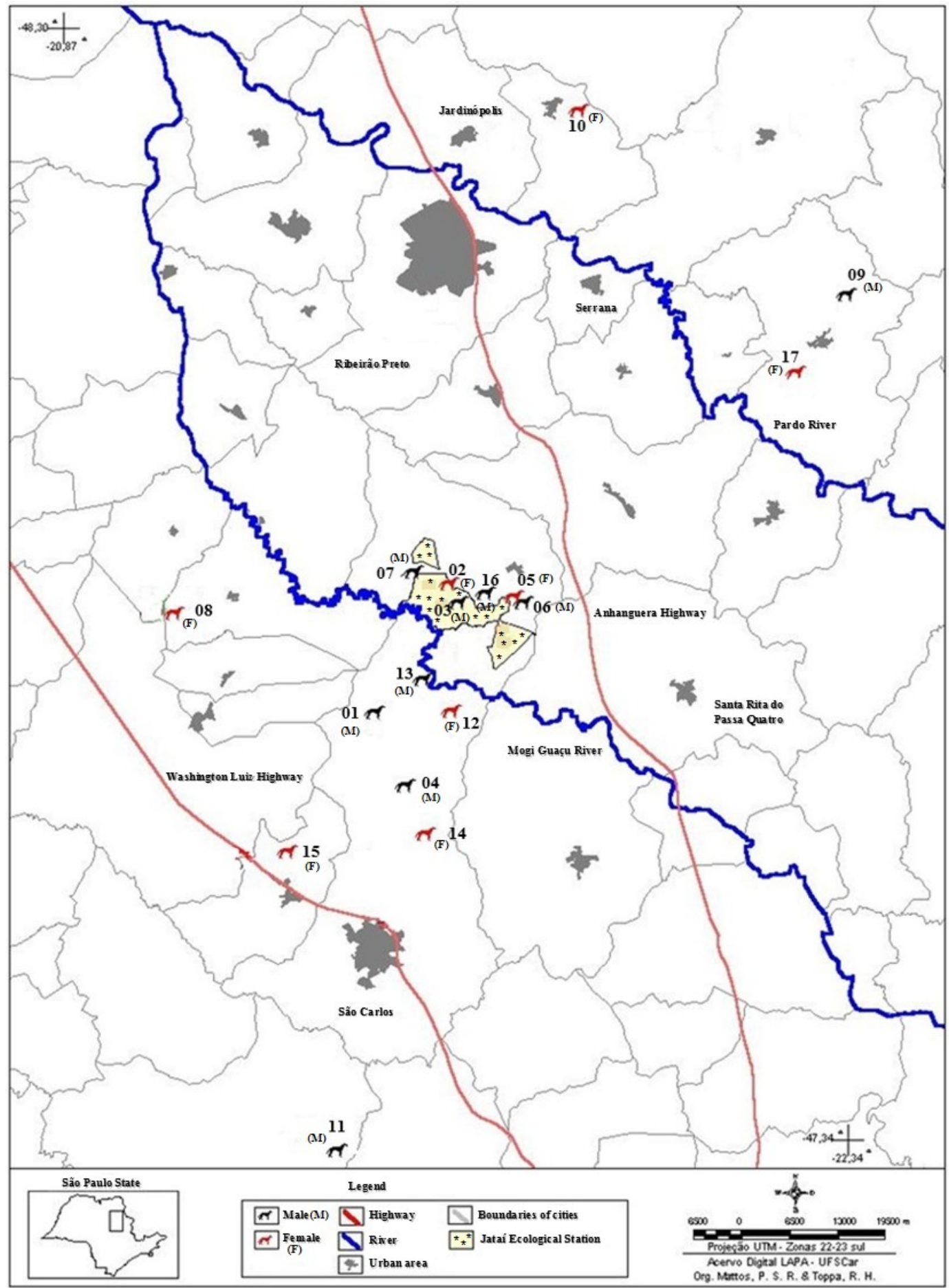

Figure 1 - Places of the capture and identification of free-ranging maned wolves (Chrysocyon brachyurus) in the northeastern region of the state of São Paulo, Brazil

Source: (MATTOS, 2003) 


\section{Serological analysis}

Serum samples were tested using the indirect fluorescent antibody test (IFAT) to detect antibodies against tachyzoites of $T$. gondii (titers $\geq 16$ ), tachyzoites of $N$. caninum ( $\geq 50$ ), promastigotes of Leishmania sp. ( $\geq 40)$, or E. canis- infected DH82 cells ( $\geq 80$ ). The RH strain of T. gondii, the NC-1 strain of $N$. caninum, strain 154 of L. amazonensis, and strain 153 of L. infantum chagasi (from the Brazilian Collection of Trypanosomatids [Coleção Brasileira de Tripanossomatídeos]), and the São Paulo strain of $E$. canis (AGUIAR et al., 2008) were used as antigens. Positive and negative controls from domestic dogs were used in each slide. Heterologous conjugate antidog IgG labeled with fluorescein isothiocyanate (FITC) (Sigma-Aldrich ${ }^{\circledR}$, St. Louis, MO, USA) was used as described by Silva et al. (2005).

\section{Results}

The presence of antibodies against $T$. gondii, $N$. caninum, Leishmania spp., or E. canis observed in maned wolves from the northeastern region of the state of São Paulo is summarized in table 1. Of the 17 maned wolves tested, 15 showed antibodies against at least one of the agents under investigation. Anti-T. gondii antibodies were detected in $88.2 \%(15 / 17)$ of the animals, anti-Leishmania sp. in $17.6 \%$ (3/17), antiE. canis in $52.9 \%(9 / 17)$, and all maned wolves tested seronegative for $\mathrm{N}$. caninum (0/17). Cross-reaction between anti-L. amazonensis and -L. infantum chagasi antibodies is common (VALE et al., 2009), and seropositive results only for the genus (Leishmania spp.) were considered in this study.

\begin{tabular}{|c|c|c|c|c|c|}
\hline \multirow{2}{*}{$\underset{\text { ID }}{\text { Animal }}$} & \multirow[b]{2}{*}{ Gender } & \multicolumn{4}{|c|}{ Titers } \\
\hline & & $\begin{array}{c}\text { Anti- } \\
\text { T. gondii }\end{array}$ & $\begin{array}{c}\text { Anti- } \\
\text { N. caninum }\end{array}$ & $\begin{array}{c}\text { Anti- } \\
\text { Leishmania spp. }\end{array}$ & $\begin{array}{c}\text { Anti- } \\
\text { E. canis }\end{array}$ \\
\hline 1 & $M$ & 256 & $<50$ & 80 & 80 \\
\hline 2 & $\mathrm{~F}$ & 32 & $<50$ & 40 & 80 \\
\hline 3 & $M$ & 128 & $<50$ & 80 & 160 \\
\hline 4 & $M$ & 128 & $<50$ & $<40$ & 160 \\
\hline 5 & $\mathrm{~F}$ & 256 & $<50$ & $<40$ & 160 \\
\hline 6 & $M$ & 128 & $<50$ & $<40$ & 320 \\
\hline 7 & $M$ & 256 & $<50$ & $<40$ & $<80$ \\
\hline 8 & $\mathrm{~F}$ & 128 & $<50$ & $<40$ & 80 \\
\hline 9 & $M$ & 128 & $<50$ & $<40$ & $\geq 1280$ \\
\hline 10 & $\mathrm{~F}$ & 512 & $<50$ & $<40$ & 80 \\
\hline 11 & $M$ & 128 & $<50$ & $<40$ & $<80$ \\
\hline 12 & $\mathrm{~F}$ & 128 & $<50$ & $<40$ & $<80$ \\
\hline 13 & $M$ & 1024 & $<50$ & $<40$ & $<80$ \\
\hline 14 & $\mathrm{~F}$ & $<16$ & $<50$ & $<40$ & $<80$ \\
\hline 15 & $\mathrm{~F}$ & 256 & $<50$ & $<40$ & $<80$ \\
\hline 16 & $M$ & $<16$ & $<50$ & $<40$ & $<80$ \\
\hline 17 & $\mathrm{~F}$ & 256 & $<50$ & $<40$ & $<80$ \\
\hline
\end{tabular}

All animals seropositive to Leishmania spp. or E. canis were also seropositive to T. gondii. Of all the animals seropositive for $T$. gondii, six were seropositive only for $T$. gondii $(40 \%, 6 / 15)$, six for $T$. gondii and E. canis $(40 \%, 6 / 15)$ and three for T. gondii, Leishmania spp. and E. canis (20\%, 3/15). 


\section{Discussion}

In the present study, antibodies against $T$. gondii were found in most of the free-ranging maned wolves tested. Of the animals, $88.2 \% \quad(15 / 17)$ were seropositive for T. gondii, while none was seropositive for $N$. caninum. Our results were similar to those of other serological surveys. Curi et al. (2012) and Proença et al. (2013) found 75\% (6/8) and 100\% (3/3) of seropositive results for $T$. gondii (modified agglutination test, MAT) in free-ranging maned wolves from the state of Minas Gerais and the Federal District, Brazil, respectively. In both studies, all animals were seronegative for $N$. caninum (IFAT). However, anti-N. caninum antibodies (IFAT) were detected in captive maned wolves in zoos in the Czech Republic (SEDLÁK; BÁRTOVÁ, 2006) and Brazil (MATTOS et al., 2008), with occurrence of $16.6 \%$ $(1 / 6)$ and $28.6 \%(4 / 14)$, respectively. As part of the management, captive carnivorous animals are fed raw meat that could be a source of T. gondii and $N$. caninum infection. The raw meat should be previously frozen to reduce the risk of infection, as suggested by Silva et al. (2007).

The presence of high levels of antibodies against $T$. gondii indicates exposure of these maned wolves to different sources of T. gondii, such as environmental contamination by sporulated oocysts and prey infected with tissue cysts. The diet of the maned wolf is variable and fluctuates according to season, availability of food, and location (MOTTA-JUNIOR et al., 1996; RODRIGUES et al., 2007). Rodents, birds, and wolf's fruit (Solanum lycocarpum) are the main components of the diet, but occasionally small and medium-sized mammals can also become prey (QUEIROLO; MOTTA-JUNIOR, 2007). When capturing the maned wolves in this study, two of the animals (IDs 8 and 9) were seen searching for food in dumps. This situation may increase the chances of transmission of infectious and parasitic diseases from domestic animals to maned wolves (MURRAY et al., 1999).
The northeastern region of the state of São Paulo is a non-endemic area for $\mathrm{VL}$, but the vector $L u$. longipalpis is present in this area and cases of canine and human visceral leishmaniasis are increasing in the state of São Paulo year by year (CIARAVOLO et al., 2015). In our findings, three animals had antiLeishmania spp. antibodies, which is consistent with other studies (CURI et al., 2006; JUSI et al., 2011). In the physical examination, none of the maned wolves showed skin lesions or clinical alterations that suggested clinical disease due to Leishmania spp. It is important to emphasize that wild animals, whether free-ranging or captive, can be reservoirs of Leishmania spp. without clinical signs and become an important source of infection for human and domestic animals (ACHA; SZYFRES, 2003). On the other hand, wild canids can be reservoirs of other trypanosomatids, such as Trypanosoma cruzi (ROCHA et al., 2013). Therefore, the possibility of cross-reaction in serologic tests among members of Trypanosomatidae family cannot to be ruled out, as has been suggested by some authors (LUCIANO et al., 2009).

Antibodies against $E$. canis had the second highest frequency of occurrence in this survey. Of the 17 maned wolves studied, nine were seropositive for $E$. canis (more than $50 \%$ of the animals tested). Ehrlichiosis in domestic dogs is well understood (LABRUNA et al., 2007). Nevertheless, there are few surveys of the occurrence of anti-Ehrlichia sp. antibodies in wild canids (PARAS et al., 2012). In Brazil, Arrais (2013) found $18.2 \%$ (16/87) of seropositive results (IFAT) for E. canis in maned wolves from the Serra da Canastra National Park in the state of Minas Gerais. The R. sanguineus tick was not found in the maned wolves; however, ticks of the genus Amblyomma were detected (data not shown). Therefore, the epidemiology of species of Ehrlichia in wild canids in Brazil requires further investigation (COSTA JUNIOR et al., 2007). 
In conclusion, this survey found that free-ranging maned wolves from the northeastern region of the state of São Paulo, Brazil, have been exposed to $T$. gondii, E. canis and, possibly, to Leishmania spp. The nature of this region, with its large industrial area, extensive agriculture, and habitat fragmentation, contributes to the contact of maned wolves with suburban areas and farms. These environmental circumstances can increase the risk of transmission of pathogens, especially zoonotic agents, between domestic and wild animals and human beings.

\section{References}

ACHA, P. N.; SZYFRES, B. Leishmaniasis visceral. In: ACHA, P. N.; SZYFRES, B. Zoonosis y enfermedades transmisibles comunes al hombre y a los animales: parasitosis. Washington, D.C.: Organización Panamericana de la Salud, 2003. p. 64-73.

AGUIAR, D. M.; HAGIWARA, M. K.; LABRUNA, M. B. In vitro isolation and molecular characterization of an Ehrlichia canis strain from São Paulo, Brazil. Brazilian Journal of Microbiology, v. 39, n. 3, p. 489-493, 2008. doi: 10.1590/S151783822008000300014 .

ARRAIS, R. C. Ocorrência de patógenos transmitidos por carrapatos (Anaplasma spp, Babesia spp, Ehrlichia spp, Hepatozoon spp e Rickettsia spp) em lobos guará (Chrysocyon brachyurus) e cães domésticos na região do Parque Nacional da Serra da Canastra, Minas Gerais, Brasil. 2013. 81 f. Dissertação (Mestrado em Epidemiologia Experimental Aplicada às Zoonoses) - Faculdade de Medicina Veterinária e Zootecnia, Universidade de São Paulo, São Paulo, 2013. doi: 10.11606/D.10.2013.tde-17072014-113127.

CHIARELlO, A. G.; AGUIAR, L. M. S.; CERQUEIRA, R.; MELO, F. R.; RODRIGUES, F. H. G.; SILVA, V. M. F. Mamíferos ameaçados de extinção no Brasil. In: MACHADO, A. B. M.; DRUMMOND, G. M.; PAGLIA, A. P. (Ed.). Livro vermelho da fauna brasileira ameaçada de extinção. Brasília, DF: Ministério do Meio Ambiente; Belo Horizonte: Fundação Biodiversitas, 2008. v. 2, p. 681-702. (Série Biodiversidade).

CIARAVOLO, R. M. C.; HENRIQUES, L. F.; RANGEL, O.; SAMPAIO, S. M. P. Vigilância entomológica e controle vetorial no Programa de Vigilância e controle da leishmaniose

\section{Acknowledgements}

P.S.R. Mattos received financial support for this study from the São Paulo Research Foundation [Fundação de Amparo à Pesquisa do Estado de São Paulo, FAPESP] (98/15168-2). S.M. Gennari and M.B. Labruna are in receipt of fellowships from the Brazilian National Council for Scientific and Technological Development [Conselho Nacional de Desenvolvimento Científico e Tecnológico, CNPq].

visceral no estado de São Paulo. Boletim Epidemiológico Paulista, v. 12, n. 135-136, p. 24-34, 2015.

COSTA JUNIOR, L. M.; REMBECK, K.; RIBEIRO, M. F. B.; BEELITZ, P.; PFISTER, K.; PASSOS, L. M. F. Sero-prevalence and risk indicators for canine ehrlichiosis in three rural areas of Brazil. The Veterinary Journal, v. 174, n. 3, p. 673-676, 2007. doi: 10.1016/j.tvjl.2006.11.002.

CURI, N. H. A.; ARAÚJO, A. S.; CAMPOS, F. S.; LOBATO, Z. I. P.; GENNARI, S. M.; MARVULHO, M. F. V.; SILVA, J. C. R.; TALAMONI, S. A. Wild canids, domestic dogs and their pathogens in Southeast Brazil: Disease threats for canid conservation. Biodiversity and Conservation, v. 19, p. 35133524, 2010.

CURI, N. H. A.; COELHO, C. M.; MALTA, M. C. C.; MAGNI, E. M. V.; SÁBATO, M. A. L.; ARAÚJO, A. S.; LOBATO, Z. I. P.; SANTOS, J. L. C.; SANTOS, H. A.; RAGOZO, A. A. M.; SOUZA, S. L. P. Pathogens of wild maned wolves (Chrysocyon brachyurus) in Brazil. Journal of Wildlife Diseases, v. 48, n. 4, p. 1052-1056, 2012. doi: 10.7589/2011-10-304.

CURI, N. H. A.; MIRANDA, I.; TALAMONI, S. A. Serologic evidence of Leishmania infection in free-ranging wild and domestic canids around a Brazilian National Park. Memórias do Instituto Oswaldo Cruz, v. 101, n. 1, p. 99101, 2006. doi: 10.1590/S0074-02762006000100019.

DIETZ, J. M. Ecology and social organization of the maned wolf (Chrysocyon brachyurus). Smithsonian Contribution to Zoology, v. 392, p. 1-51, 1984. 
DUBEY, J. P. Neosporosis in dogs. CAB Reviews, v. 8, n. 55, p. 1-26, 2013. doi: 10.1079/PAVSNNR20138055.

DUBEY, J. P. Toxoplasmosis of animals and humans. $2^{\text {nd }} \mathrm{ed.}$ Boca Raton: CRC Press, 2010. 313 p.

DUBEY, J. P.; BEATTIE, C. P. Toxoplasmosis of animals and man. Boca Raton: CRC Press, 1988. 220 p.

DUBEY, J. P.; SCHARES, G. Neosporosis in animals - the last five years. Veterinary Parasitology, v. 180, n. 1-2, p. 90-108, 2011. doi: 10.1016/j.vetpar.2011.05.031.

FERREIRA, P. R. B.; LARANJEIRA, D. F.; OLIVEIRA, L. S.; MALTA, M. C. C.; GOMES, M. C.; BASTOS, B. L.; PORTELA, R. W.; BARROUIN-MELO, S. M. Indirect ELISA for the serological diagnosis of visceral leishmaniasis in wild canids. Pesquisa Veterinária Brasileira, v. 33, n. 4, p. 528-534, 2013. doi: 10.1590/S0100-736X2013000400018.

FIGUEIREDO, F. B.; GREMIÃO, I. D. F.; PEREIRA, S. A.; FEDUlO, L. P.; MENEZES, R. C.; BALTHAZAR, D. A.; SCHUBACH, T. M.; MADEIRA, M. F. First report of natural infection of a bush dog (Speothos venaticus) with Leishmania (Leishmania) chagasi in Brazil. Transactions of the Royal Society of Tropical Medicine and Hygiene, v. 102, n. 2, p. 200-201, 2008. doi: 10.1016/j.trstmh.2007.10.001.

JUSI, M. M. G.; STARKE-BUZETTI, W. A.; OLIVEIRA, T. M. F. S.; TENÓRIO, M. S.; SOUSA, L. O. S.; MACHADO, R. Z. Molecular and serological detection of Leishmania spp. in captive wild animals from Ilha Solteira, SP, Brazil. Revista Brasileira Parasitologia Veterinária, v. 20, n. 3, p. 219-222, 2011. doi: 10.1590/S1984-29612011000300008.

LABRUNA, M. B.; MCBRIDE, J. W.; CAMARGO, L. M. A.; AGUIAR, D. M.; YABSLEY, M. J.; DAVIDSON, W. R.; STROMDAHL, E. Y.; WILLIAMSON, P. C.; STICH, R. W.; LONG, S. W.; CAMARGO, E. P.; WALKER, D. H. A preliminary investigation of Ehrlichia species in ticks, humans, dogs, and capybaras from Brazil. Veterinary Parasitology, v. 143, n. 2, p. 189-195, 2007. doi: 10.1016/j.vetpar.2006.08.005.

LUCIANO, R. M.; LUCHEIS, S. B.; TRONCARELLI, M. Z.; LUCIANO, D. M.; LANGONI, H. Avaliação da reatividade cruzada entre antígenos de Leishmania spp e Trypanosoma cruzi na resposta sorológica de cães pela técnica de imunofluorescência indireta (RIFI). Brazilian Journal of Veterinary Research and Animal Science, v. 46, n. 3, p. 181187, 2009. doi: 10.1590/S1413-95962009000300003.
LUPPI, M. M.; MALTA, M. C. C.; SILVA, T. M. A.; SILVA, F. L.; MOTTA, R. O. C.; MIRANDA, I.; ECCO, R.; SANTOS, R. L. Visceral leishmaniasis in captive wild canids in Brazil. Veterinary Parasitology, v. 155, n. 1-2, p. 146-151, 2008. doi: 10.1016/j.vetpar.2008.04.024.

MATTOS, B. C.; PATRÍCIO, L. L. F.; PLUGGE, N. F. R.; LANGE, R. R.; RICHARTZ, R. R. T. B.; LOCATELLIDITTRICH, R. Soroprevalência de anticorpos anti-Neospora caninum e anti-Toxoplasma gondii em canídeos selvagens cativos. Revista Brasileira Parasitologia Veterinária, v. 17, p. 267-272, 2008. Supplement 1.

MATTOS, P. S. R. Epidemiologia e genética populacional do lobo-guará, Chrysocyon brachyurus (Illiger, 1915) (Carnívora, Canidae) na região nordeste do Estado de São Paulo. 2003. 85 f. Tese (Doutorado em Ciências) Universidade Federal de São Carlos, São Carlos, 2003.

MOTTA-JUNIOR, J. C.; TALAMONI, S. A.; LOMBARDI, J. A.; SIMOKOMAKI, K. Diet of maned wolf, Chrysocyon brachyurus, in central Brazil. Journal of Zoology, v. 240, n. 2, p. 277-284, 1996. doi: 10.1111/j.1469-7998.1996.tb05284.x.

MURRAY, D. L.; KAPKE, C. A.; EVERMANN, J. F.; FULLER, T. K. Infectious disease and the conservation of free-ranging large carnivores. Animal Conservation, v. 2, n. 4, p. 241-254, 1999. doi: 10.1111/j.1469-1795.1999.tb00070.x.

NOVAES, A. P. Contenção farmacológica de animais. 2. ed. São Carlos: EMBRAPA-CPPSE, 1997. p. 106.

PARAS, K. L.; LITTLE, S. E.; REICHARD, M. V.; REISKIND, M. H. Detection of Dirofilaria immitis and Ehrlichia Species in coyotes (Canis latrans), from Rural Oklahoma and Texas. Vector-Borne Zoonotic Diseases, v. 12, n. 7, p. 619-621, 2012. doi: 10.1089/vbz.2011.0815.

PROENÇA, L. M.; SILVA, J. C. R.; GALERA, P. D.; LION, M. B.; MARINHO-FILHO, J. S.; RAGOZO, A. M. A.; GENNARI, S. M.; DUBEY, J. P.; VASCONCELLOS, S. A.; SOUZA, G. O.; PINHEIRO JUNIOR, J. W.; SANTANA, V. L. A.; FRANÇA, G. L.; RODRIGUES, F. H. G. Serologic survey of infectious diseases in populations of maned wolf (Chrysocyon brachyurus) and crab-eating fox (Cerdocyon thous) from Águas Emendadas Ecological Station, Brazil. Journal of Zoo and Wildlife Medicine, v. 44, n. 1, p. 152-155, 2013. doi: 10.1638/1042-7260-44.1.152. 
QUEIROLO, D.; MOTTA-JUNIOR, J. C. Prey availability and diet of maned wolf in Serra da Canastra National Park, southeastern Brazil. Acta Theriologica, v. 52, n. 4, p. 391-402, 2007. doi: 10.1007/BF03194237.

ROCHA, F. L.; ROQUE, A. L. R.; LIMA, J. S.; CHEIDA, C. C.; LEMOS, F. G.; AZEVEDO, F. C.; ARRAIS, R. C.; BILAC, D.; HERRERA, H. M.; MOURÃO, G.; JANSEN, A. M. Trypanosoma cruzi infection in neotropical wild carnivores (Mammalia: Carnivora): at the top of the T. cruzi transmission chain. PLoS One, v. 8, n. 7, p. 1-12, 2013. doi: 10.1371/journal.pone.0067463.

RODDEN, M.; RODRIGUES, F.; BESTELMEYER, S. Chrysocyon brachyurus. In: IUCN red list of threatened species 2010. November, 2008: Version 2008. Available from: <http://www.iucnredlist.org>. Viewed: 12 Sept. 2015.

RODRIGUES, F. H. G.; HASS, A.; LACERDA, A. C. R.; GRANDO, R. L. S. C.; BAGNO, M. A.; BEZERRA, A. M. R.; SILVA, W. R. Feeding habits of the maned wolf (Chrysocyon brachyurus) in the Brazilian cerrado. Mastozoologia Neotropical, v. 14, n. 1, p. 37-51, 2007. Available from: <http://www.scielo.org.ar/pdf/mznt/v14n1/v14n1a05.pdf>. Viewed: 29 Sept. 2015.

SANTOS, S. O.; ARIAS, J.; RIBEIRO, A. A.; HOFFMANN, M. P.; FREITAS, R. A.; MALACCO, M. A. F. Incrimination of Lutzomyia cruzi as a vector of American visceral leishmaniasis. Medical and Veterinary Entomology, v. 12, n. 3, p. 315-317, 1998. doi: 10.1046/j.1365-2915.1998.00104.x.

SEDLÁK, K.; BÁRTOVÁ, E. Seroprevalences of antibodies to Neospora caninum and Toxoplasma gondii in zoo animals. Veterinary Parasitology, v. 136, n. 3-4, p. 223-231, 2006. doi: 10.1016/j.vetpar.2005.11.021.

SILVA, D. A. O.; VITALIANO, S. N.; MINEO, T. W. P.; FERREIRA, R. A.; BEVILACQUA, E.; MINEO, J. R.
Evaluation of homologous, heterologous, and affinity conjugates for the serodiagnosis of Toxoplasma gondii and Neospora caninum in maned wolves (Chrysocyon brachyurus). Journal of Parasitology, v. 91, n. 5, p. 12121216, 2005. doi: 10.1645/GE-527R.1.

SILVA, J. C. R.; MARVUlO, M. F. V.; DIAS, R. A.; FERREIRA, F.; AMAKU, M.; ADANIA, C. H.; FERREIRA NETO, J. S. Risk factors associated with sero-positivity to Toxoplasma gondii in captive neotropical felids from Brazil. Preventive Veterinary Medicine, v. 78, n. 3-4, p. 286-295, 2007. doi: 10.1016/j.prevetmed.2006.10.013.

STICH, R. W.; SCHAEFER, J. J.; BREMER, W. G.; NEEDHAM, G. R.; JITTAPALAPONG, S. Host surveys, ixodid tick biology and transmission scenarios as related to the tick-borne pathogen. Ehrlichia canis. Veterinary Parasitology, v. 158, n. 4, p. 256-273, 2008. doi: 10.1016/j.vetpar.2008.09.013.

VALE, A. M.; FUJIWARA, R. T.; SILVA NETO, A. F.; MIRET, J. A.; ALVAREZ, D. C. C.; SILVA, J. C. F.; CAMPOS-NETO, A.; REED, S.; MAYRINK, W.; NASCIMENTO, E. Identification of highly specific and cross-reactive antigens of Leishmani species by antibodies from Leishmania (Leishmania) chagasi naturally infected dogs. Zoonoses and Public Health, v. 56, n. 1, p. 41-48, 2009. doi: 10.1111/j.18632378.2008.01183.x.

VITALIANO, S. N.; SILVA, D. A. O.; MINEO, T. W. P.; FERREIRA, R. A.; BEVILACQUA, E.; MINEO, J. R. Seroprevalence of Toxoplasma gondii and Neospora caninum in captive maned wolves (Chrysocyon brachyurus) from southeastern and midwestern regions of Brazil. Veterinary Parasitology, v. 122, n. 4, p. 253-260, 2004. doi: 10.1016/j.vetpar.2004.04.004.

YU, X. J.; MCBRIDE, J. W.; WALKER, D. H. Restriction and expansion of Ehrlichia strain diversity. Veterinary Parasitology, v. 143, n. 3-4, p. 337-346, 2007. doi: 10.1016/j.vetpar.2006.08.027. 